\title{
RELATIONSHIPS AND ESTIMATES OF LONGITUDINAL GROWTH STRESS IN Eucalyptus dunnii AT DIFFERENT AGES ${ }^{1}$
}

\author{
Paulo Fernando Trugilho² e José Tarcísio da Silva Oliveira ${ }^{3}$
}

\begin{abstract}
The objective of this study was to obtain estimates of longitudinal growth stresses in standing trees of the Eucalyptus dunnii Maiden at eight, thirteen, fifteen and nineteen years of age and to determine their relationships with wood characteristics. The longitudinal growth stresses were indirectly measured by the "CIRAD-Forêt" method and estimated from both the dynamic modulus of elasticity and the modulus of elasticity in tension parallel to the grain. The longitudinal residual strain (LRS) and the estimates of the longitudinal growth stresses tended to increase with the age of the material. The LRS correlated positively and significantly with all the growth stresses estimates. The largestes magnitudes were at 13, 15 and 19 years of age. The basic density presented high, positive and significant correlations with the dynamic modulus of elasticity, estimated in the longitudinal direction, for wood saturated and at $12 \%$ moisture content, for all the ages assessed. All the growth stresses estimates presented high, positive and significant correlations between themselves.
\end{abstract}

Keywords: Growth stress, longitudinal residual strain and standing tree.

\section{RELAÇÕES E ESTIMATIVAS DA TENSÃO DE CRESCIMENTO LONGITUDINAL EM Eucalyptus dunnii MAIDEN}

\begin{abstract}
RESUMO - O objetivo desse trabalho foi obter estimativas da tensão de crescimento longitudinal em árvores vivas e verificar a sua relação com algumas características da madeira de Eucalyptus dunnii Maiden aos oito, treze, quinze e dezenove anos de idade. O material foi proveniente da Empresa Procopiak Compensados e Embalagens S.A., localizada no Município de Canoinhas, Santa Catarina. Os níveis de tensão longitudinal de crescimento foram mensurados indiretamente pelo método do "CIRAD-Forêt", na árvore viva, e estimados a partir do módulo de elasticidade dinâmico e do módulo de elasticidade obtido no ensaio de tração paralela à grã. A deformação residual longitudinal (DRL) e as estimativas das tensões de crescimento longitudinais apresentaram tendência de aumento, na média, com a idade do material. A DRL apresentou correlação, positiva e significativa, com todas as estimativas das tensões de crescimento longitudinais, sendo de maior magnitude aos 13, 15 e 19 anos de idade. A densidade básica apresentou maiores correlações, positivas e significativas, com o módulo de elasticidade dinâmico, estimado no sentido longitudinal, para a madeira na condição de saturação e a $12 \%$ de umidade, em todas as idades avaliadas. Todas as estimativas das tensões de crescimento longitudinais apresentam elevadas correlações, positivas e significativas, entre si.
\end{abstract}

Palavras-Chave: Deformação residual longitudinal, árvore viva e eucalipto.

\footnotetext{
${ }^{1}$ Recebido em 18.10.2006 e aceito para publicação em 19.05.2008.

${ }^{2}$ Laboratório de Tecnologia da Madeira da Universidade Federal de Lavras (UFLA), Lavras-MG. E-mail: <trugilho@ufla.br> .

${ }^{3}$ Departamento de Engenharia Rural da Universidade Federal do Espírito Santo (UFES). E-mail: <jtsilva@npd.ufes.br>.
} 


\section{INTRODUCTION}

Growth stresses in trees cause significant waste of wood due to defects, such as warping and splits, that appear immediately after felling the tree and when sawing the logs. As this phenomenon is variable, it has been studied aiming to determine how it is influenced by factors related to the tree growth, such as forest management, silviculture, heredity, soil, climate etc. and which practices can be used to minimize it (POLGE and THIERCELIN, 1979). In Eucalyptus the growth stress is perhaps the most important property when it is used for solid wood.

These growth stresses are found in the trunk of green trees and can be longitudinal, tangential and radial (KUBLER, 1987). The longitudinal growth stresses are the most intense and variable. For this reason they have been subject of various studies.

Growth stresses originate in the cambium region of the tree trunks, during maturation of the cells (WILHELMY and KUBLER, 1973). They tend to contract longitudinally and, at the same time, expand laterally. Since these cells are integral parts of the tree tissues, they are almost completely prevented from suffering these dimensional alterations (WILHELMY and KUBLER, 1973). According to Wilkins (1986) there are two more accepted hypotheses to explain the cause of these tensions, one proposed by Watanabe and Boyd, that associates the swelling of the cell wall and consequent traction of the cellulose molecule to lignin deposition; and another by Kubler, who proposed that the shortening of the peripheral cells results from the contraction of the cellulose crystals of the microfibrils in the $\mathrm{S}_{2}$ layer.

After felling the tree down, the peripheral zone of the log, under traction, tends to contract and the central part, under compression, to expand (MALAN, 1979). These growth stresses are in equilibrium in the standing tree, acting as a way of giving them stability (van WYK, 1978), but as soon it is felled, deformations and end splits occur on the logs (FERRAND, 1983).

Longitudinal peripheral strain can be determined by the stress release given by two holes perforated above and below a measuring extensometer fixed on the tree stem. Peripheral strain measurements on the trunk refer only to the most recently formed wood. According to Archer (1986), this method is relatively simple, quick, only locally destructive and is applied on the standing tree. The circumferential tensions along the length of logs and trees can be examined in detail. Thus, trees can be assessed in terms of intensity and variations of growth stresses aiming forest management or genetical improvement. The perforation of the holes gives an estimate of the total release of the deformations close to them, $15 \%$ lower to the value obtained with the complete removal of the piece of wood (NICHOLSON, 1971). Consequently this method is only indicated for field studies, when an approximate intensity of the growth deformations, their peripheral distribution and their variation among trees and species are required. This method is called the Nicholson method. CIRADForêt developed an equipment to determine the longitudinal strains in standing trees, that can be considered nondestructive because of the little physical damage to the stem. This method consists of fixing an extensometer on two pins distanced $45 \mathrm{~mm}$ on the trunk, in the direction of the grain and to make a hole between them, when the stress is partially released. As a consequence the two pins will move apart, indicating a longer distance. The difference between the two distances will be the longitudinal residual strain.

After determining the strains of a piece compared to its length, this value is multiplied by the corresponding modulus of elasticity determined on the same piece and where the alteration in length was measured. Or more simply, by multiplying it by the mean value of this module, determined in laboratory for the species in question to estimate the growth stresses (LISBOA, 1993). An alternative would be obtaining the dynamic modulus of elasticity, for example, by the stress wave timer on wood samples removed from the measuring regions of the peripheral strains of the stem.

The knowledgement of the peripheral strain is of practical importance, although it does not inform the magnitude and distribution of the growth stresses inside the stem. For this, the so-called Jacobs method can be used. This method is described in detail by Archer (1986) and will not be discussed here.

The objective of this study was to obtain longitudinal growth stresses estimates in Eucalyptus dunnii Maiden trees at 8,13, 15 and 19 years of age.

\section{MATERIALAND METHODS}

Eucalyptus dunnii trees at 8, 13, 15 and 19 years of age were used. The populations were established 
by saplings derived from seeds, and each tree was considered as a different genotype. Twelve trees were assessed at eight years and 16 trees at the other ages, totaling of 60 trees. The trees were randomly selected in the plantations, taking care to choose the most representative according to the diametric classes. Trees from the borders and those that presented disease symptoms were not selected. The 15 year-old trees were cultivated at São João dos Cavaleiros farm, while the others were cultivated at Rio da Areia farm.

This material was supplied by the Procopiak Corp., located at Canoinhas region, on the Northern plateau of Santa Catarina State, Brazil. The latitude is $26^{\circ} 10^{\prime} \mathrm{S}$ and longitude $50^{\circ} 23^{\prime} \mathrm{W}$ of Greenwich and the altitude $734 \mathrm{~m}$. According to the Köppen classification, the climate is the Cfa type, temperate climate without a dry season and rainfall well distributed throughout the year. The average annual temperature is $18^{\circ} \mathrm{C}$ and the rainfall varies from 1800 to $2400 \mathrm{~mm}$ (SECRETARIA DE ESTADODAAGRICULTURAE POLÍTICARURAL DE SANTA CATARINA, 2003).

The longitudinal residual strain (LRS) was measured with the CIRAD-Forêt instrument (growth stress gauge), and was carried out at $1.30 \mathrm{~m}$ of height on the tree stem (DBH). The cardinal positions were marked around the stem. The stress wave emission methodology was applied in the same place, in the diametral direction of the stem, in the Northwest and Eastwest orientation. During the measuring, the diameters (DBH) of the trees were obtained with a tape measure. The total heights (TH) of the trees were measured after felling.

The basal $3 \mathrm{~m}$ long log was taken to the sawmill where two opposite slabs were removed from each, in the same position where LRS was measured. A stick measuring $5.0 \times 2.5 \times 50.0 \mathrm{~cm}$ was removed from each slab, to be submitted to the stress wave emission.

The shavings collected while measuring the LRS were used to determine the basic density according to the maximum moisture content method [Equation 1].

$$
\mathrm{BD}=\frac{1}{\frac{\mathrm{Sm}}{\mathrm{Dm}}-0,34641}
$$

where $\mathrm{BD}$ is the basic density, determined by the maximum moisture content method $\left(\mathrm{g} / \mathrm{cm}^{3}\right)$; Sm is the saturated in water mass, in grams; Dm is the absolutely dry mass, in grams.
The stress wave was applied to the wood stick both in the saturated and at $12 \%$ moisture content. The time of the stress wave propagation was recorded in microseconds. The same material was used to determine tension strength parallel to the grain according to the standard D-143-94 of the American Society for Testing and Materials (1997).

The dynamic modulus of elasticity was obtained by the equation 2 .

$$
\mathrm{MOEd}=\mathrm{BD}^{*} \mathrm{~V}^{2} * \frac{1}{\mathrm{~g}} * 10^{-4}
$$

where MOEd is the dynamic modulus of elasticity, in $\mathrm{kgf} / \mathrm{cm}^{2}$, in the diametral direction, in the standing tree, and in the longitudinal direction with wood both in the saturation and $12 \%$ moisture content conditions; $\mathrm{V}$ is the velocity of the stress wave, in $\mathrm{m} / \mathrm{s}$, calculated by the equation 3; $\mathrm{g}$ is the acceleration of gravity (9.804 $\mathrm{m} / \mathrm{s}^{2}$ ) and $10^{-4}$ is the correction for the units. The longitudinal growth stress was calculated by the equation 4 .

$$
\mathrm{V}=\frac{\mathrm{d}}{\mathrm{t}}
$$

where $\mathrm{d}$ is the distance in meter between transducers (debarked diameter of the stem for diametral velocity and $0,50 \mathrm{~m}$ for longitudinal velocity of the saturated and $12 \%$ moisture content) and $t$ is the time in second.

$$
\mathrm{LGS}=\frac{\mathrm{LRS} * \mathrm{MOE}}{45}
$$

where LGS is the longitudinal growth stress, in kgf/ $\mathrm{cm}^{2}$, with wood both in the saturated ( $\mathrm{LGS}_{\text {sat }}$ ) and $12 \%$ moisture content $\left(\mathrm{LGS}_{12}\right)$, LRS is the longitudinal residual strain, in mm; MOE can be either the dynamic modulus of elasticity $\left(\mathrm{MOE}_{\mathrm{D}}\right)$ or the static modulus of elasticity in tension parallel to the grain $\left(\mathrm{MOE}_{\mathrm{T}}\right)$, in $\mathrm{kgf} / \mathrm{cm}^{2}$.

\section{RESULTS AND DISCUSSION}

Table 1 presents the average values of the Eucalyptus dunnii tree growth characteristics, the longitudinal residual strain (LRS) and the wood basic density (BD) with their respective coefficients of variation $(\mathrm{CV})$. It is verified that the basic density tends to be increased with age up to 15 years and then decreased slightly at 19 years of age. This fact may be related to the wood maturation from the juvenile stage. This effect was not observed for LRS that tends to increase

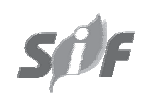

R. Árvore, Viçosa-MG, v.32, n.4, p.723-729, 2008 
with age. The coefficients of variation can be considered low, except for LRS. The LRS values are accord with Trugilho et al. (2004) and Lima et al. (2004), however lightly larger.

Table 2 presents the average velocity of the stress wave in the diametral direction $\left(V_{E} L_{D}\right)$, the average velocity of the stress wave in the longitudinal direction for both saturated $\left(\mathrm{VEL}_{\text {sat }}\right)$ and $12 \%$ moisture content $\left(V L_{12}\right)$ wood and the estimates of the dynamic modulus of elasticity in the diametral direction $\left(\mathrm{MOEd}_{\mathrm{D}}\right)$, modulus of elasticity in the longitudinal direction for both saturated $\left(\right.$ MOEd $\left._{\text {sat }}\right)$ and $12 \%$ moisture content $\left(\operatorname{MOEd}_{12}\right)$ wood, with their respective coefficients of variation (CV). The stress wave velocity and the dynamic modulus of elasticity, in the longitudinal direction, was higher for green wood than for $12 \%$ moisture content wood, which is in line with results obtained by Kang and Booker (2002).

The mean stress wave velocity in the diametral direction $\left(V_{E} L_{D}\right)$ was lower than that observed in the longitudinal direction $\left(\mathrm{VEL}_{\text {sat }}\right)$, for saturated specimens. This fact was probably associated to the acoustical damping caused by the crossing the lignin, that is an amorphous and inelastic polymer (Matos, 1997). This reduction in the stress wave velocity possibly occurred because the wave passed throughout regions with different properties in the diametral direction of the stem.

This fact suggests the existence of internal defects commonly found in Eucaplyptus dunnii, such as knots and kino veins. The low stress wave velocity reflects in the low value of the dynamic modulus of elasticity in the diametral direction $\left(\mathrm{MOEd}_{\mathrm{D}}\right)$. In spite of the reduced values of the dynamic modulus of elasticity a tendency of growth was observed associated with the increase of the age. The coefficients of variation were higher for MOEd $_{\mathrm{D}}$ than both MOEd $\mathrm{dat}_{\text {and }}$ anOEd ${ }_{12}$, except for eight years of the trees age.

Table 3 presents the average values of the modulus of elasticity $\left(\mathrm{MOE}_{\mathrm{T}}\right)$, tension strength parallel to the grain ( $\mathrm{TS}_{\mathrm{p}}$ ) and the estimates of the longitudinal growth stresses using $\mathrm{MOE}_{\mathrm{T}}\left(\mathrm{LGS}_{\mathrm{T}}\right), \mathrm{MOEd}_{\mathrm{sat}}\left(\mathrm{LGS}_{\mathrm{sat}}\right)$ and $\operatorname{MOEd}_{12}\left(\mathrm{LGS}_{12}\right)$ with their respective coefficients of variation $(\mathrm{CV})$.

Table 1 - Average values for the Eucalyptus dunnii tree growth characteristics, longitudinal residual strain and basic density Tabela 1 - Valores médios para as características de crescimento, a deformação residual longitudinal e densidade básica

\begin{tabular}{|c|c|c|c|c|c|}
\hline Age (years) & Farm & $\mathrm{DBH}(\mathrm{cm})$ & TH (m) & LRS (mm) & $\mathrm{BD}\left(\mathrm{g} / \mathrm{cm}^{3}\right)$ \\
\hline \multirow[t]{2}{*}{8} & Rio da Areia & 25.70 & 27.41 & 0.107 & 0.478 \\
\hline & CV (\%) & 17.96 & 6.56 & 23.66 & 12.62 \\
\hline \multirow[t]{2}{*}{13} & Rio da Areia & 38.00 & 36.80 & 0.113 & 0.511 \\
\hline & CV (\%) & 14.24 & 8.95 & 33.02 & 8.57 \\
\hline \multirow[t]{2}{*}{15} & São João & 42.50 & 43.53 & 0.111 & 0.547 \\
\hline & CV (\%) & 15.61 & 5.57 & 26.64 & 5.25 \\
\hline \multirow[t]{2}{*}{19} & Rio da Areia & 47.20 & 44.46 & 0.123 & 0.483 \\
\hline & CV (\%) & 13.59 & 3.68 & 35.88 & 8.56 \\
\hline
\end{tabular}

Table 2 -Average stress wave velocity values and dynamic modulus of elasticity estimates for Eucalyptus dunnii at different ages Tabela 2 - Valores médios para as velocidades de propagação da onda de tensão e estimativas dos módulos de elasticidade dinâmicos

\begin{tabular}{|c|c|c|c|c|c|c|c|}
\hline \multirow[t]{2}{*}{ Age (years) } & \multirow[t]{2}{*}{ Farm } & \multicolumn{3}{|c|}{ Stress Wave Velocity (m/s) } & \multicolumn{3}{|c|}{ Dynamic Modulus of Elasticity $\left(\mathrm{kgf} / \mathrm{cm}^{2}\right)$} \\
\hline & & $\mathrm{VEL}_{\mathrm{D}}$ & $\mathrm{VEL}_{\text {sat }}$ & $\mathrm{VEL}_{12}$ & MOEd $_{D}$ & MOEd $_{\text {sat }}$ & MOEd $_{12}$ \\
\hline \multirow[t]{2}{*}{8} & Rio da Areia & 347.35 & $3,859.56$ & $5,045.98$ & 571.36 & $71,417.96$ & $121,078.82$ \\
\hline & $\mathrm{CV}(\%)$ & 6.76 & 6.67 & 3.19 & 17.54 & 22.81 & 17.08 \\
\hline \multirow[t]{2}{*}{13} & Rio da Areia & 439.78 & $4,076.95$ & $5,209.45$ & $1,065.91$ & $87,048.72$ & $141,645.72$ \\
\hline & $\mathrm{CV}(\%)$ & 25.32 & 5.14 & 3.28 & 53.26 & 14.26 & 11.22 \\
\hline \multirow[t]{2}{*}{15} & São João & 498.65 & $4,362.09$ & $5,325.18$ & $1,463.99$ & $106,581.50$ & $158,445.44$ \\
\hline & CV (\%) & 25.21 & 4.24 & 3.18 & 53.58 & 11.37 & 8.53 \\
\hline \multirow[t]{2}{*}{19} & Rio da Areia & 578.21 & $4,088.51$ & $5,276.17$ & $1,692.89$ & $82,910.37$ & $137,616.48$ \\
\hline & CV (\%) & 20.06 & 6.03 & 3.88 & 37.67 & 15.71 & 12.22 \\
\hline
\end{tabular}

R. Árvore, Viçosa-MG, v.32, n.4, p.723-729, 2008 
Table 3 - Average values of the tension strength parallel to grain and the estimates of the longitudinal growth stresses Tabela 3 - Valores médios do ensaio de tração paralela à grã e estimativas das tensões longitudinais de crescimento

\begin{tabular}{|c|c|c|c|c|c|c|}
\hline \multirow[t]{2}{*}{ Age (years) } & \multirow[t]{2}{*}{ Farm } & \multirow[t]{2}{*}{$\mathrm{TS}_{\mathrm{p}}\left(\mathrm{kgf} / \mathrm{cm}^{2}\right)$} & \multirow[t]{2}{*}{$\mathrm{MOE}_{\mathrm{T}}\left(\mathrm{kgf} / \mathrm{cm}^{2}\right)$} & \multicolumn{3}{|c|}{ Stress $\left(\mathrm{kgf} / \mathrm{cm}^{2}\right)$} \\
\hline & & & & $\mathrm{LGS}_{\mathrm{T}}$ & $\mathrm{LGS}_{\text {sat }}$ & $\mathrm{LGS}_{12}$ \\
\hline \multirow[t]{2}{*}{8} & Rio da Areia & 1385 & 169225 & 368 & 153 & 261 \\
\hline & CV (\%) & 18,66 & 19,81 & 25,84 & 27,29 & 22,49 \\
\hline \multirow[t]{2}{*}{13} & Rio da Areia & 1558 & 213255 & 544 & 220 & 358 \\
\hline & $\mathrm{CV}(\%)$ & 22,18 & 19,23 & 43,48 & 38,16 & 36,63 \\
\hline \multirow[t]{2}{*}{15} & São João & 1800 & 260499 & 648 & 265 & 392 \\
\hline & CV (\%) & 24,59 & 14,03 & 33,58 & 33,36 & 31,37 \\
\hline \multirow[t]{2}{*}{19} & Rio da Areia & 1609 & 212282 & 602 & 233 & 384 \\
\hline & CV (\%) & 20,30 & 15,96 & 46,49 & 43,89 & 41,46 \\
\hline
\end{tabular}

The modulus of elasticity in tension parallel to the grain $\left(\mathrm{MOE}_{\mathrm{T}}\right)$ was superior to both the dynamic modulus of elasticity obtained in the longitudinal direction and to wood at $12 \%$ moisture content $\left(\mathrm{MOEd}_{12}\right)$ at all ages assessed. This reflected directly on the estimates of the longitudinal growth stress used in MOEt. This estimate (LGSt) was higher than that obtained by Boyd (1950) apud Gaiotto (1993) (70 to $280 \mathrm{kgf} / \mathrm{cm}^{2}$ ). Trugilho et al. (2002) assessed Eucalyptus clones at six years of age planted in Minas Gerais State, Brazil, and reported longitudinal growth stress ranging from 139 to 448 $\mathrm{kgf} / \mathrm{cm}^{2}$, using $\mathrm{MOE}_{\mathrm{T}}$ obtained for wood with $12 \%$ moisture content. The growth stress estimates presented the same behaviour as LRS (Table 1), increasing with the age of the material.

Table 4 presents the matrix of correlations obtained between the characteristics assessed in wood for each age. It is observed that the basic density (BD) correlated positively and significantly at the level of $5 \%$ probability, but with low magnitude, with the stress wave velocity, in the longitudinal direction, for green $\left(\mathrm{VEL}_{\text {sat }}\right)$ and the $12 \%$ moisture content $\left(\mathrm{VEL}_{12}\right)$ wood and with the dynamic modulus of elasticity $\left(\mathrm{MOEd}_{\mathrm{D}}\right)$, diametral direction, only at eight years of age. The BD presented high, positive and significant correlations at the level of $1 \%$ probability with the dynamic modulus of elasticity estimated in the longitudinal direction, for saturated $\left(\mathrm{MOEd}_{2}\right)$ and the $12 \%$ moisture content $\left(\mathrm{MOEd}_{12}\right)$ wood, at all ages assessed. The correlation between BD and the longitudinal growth stress $\left(\mathrm{LGS}_{\mathrm{T}}\right.$ ) using the modulus of elasticity the tension parallel to the grain was only positive and significant for the age of 15 years. Lima et al. (2004) found some result in eucalypts with similar age. The BD presented positive and significant correlation with the longitudinal growth stress estimates using the dynamic modulus of elasticity, longitudinal direction in both green ( $\mathrm{LGS}_{\mathrm{sat}}$ ) and $12 \%$ moisture content $\left(\mathrm{LGS}_{12}\right)$ wood at the ages of eight and 15 years.

The longitudinal residual strain (LRS) correlated positively and significantly with the estimates of the longitudinal growth stress $\left(\mathrm{LGS}_{\text {sat }}, \mathrm{LGS}_{12}\right.$ and $\mathrm{LGS}_{\mathrm{T}}$ ), and with greatest magnitude at 13, 15 and 19 years of age. This fact indicated that the LRS participated decisively in the estimate of the longitudinal growth stress, because its influence on the estimates of these stresses was greater than that of the modulus of elasticity. It also indicated that LRS can be used as an indirect and reliable estimate of the longitudinal growth stress in the standing tree.

The modulus of elasticity in tension parallel to the grain test $\left(\mathrm{MOE}_{\mathrm{T}}\right)$ did not correlate with the stress wave velocity in the diametral direction $\left(\mathrm{VEL}_{\mathrm{D}}\right)$ at any age. However, it correlated positively and significantly with the stress wave velocity in the longitudinal direction and in green wood ( $\left.\mathrm{VEL}_{\text {sat }}\right)$, at all the ages, and with the stress wave velocity in the longitudinal direction and in wood with $12 \%$ of moisture content $\left(\mathrm{VEL}_{12}\right)$ at 13, 15 and 19 years of age. The $\mathrm{MOE}_{\mathrm{t}}$ presented positive and significant correlation with the longitudinal growth stress estimates obtained using the dynamic modulus of elasticity, for green $\left(\mathrm{LGS}_{\text {sat }}\right.$ ) and with $12 \%$ of moisture content $\left(\mathrm{LGS}_{12}\right)$ wood at all the ages.

The stress wave velocity in the diametral direction presented non-significant and low magnitude correlation with the stress wave velocity in the longitudinal direction, and green wood condition, at the ages.

All the estimates of the longitudinal growth stress presented high, positive and significant correlations. This fact indicated that determining the longitudinal growth stress for saturated wood is sufficient to estimate its level of variation within the tree.

R. Árvore, Viçosa-MG, v.32, n.4, p.723-729, 2008 
Table 4 - Matrix of correlation obtained between the characteristics assessed in the wood for age Tabela 4 - Matriz de correlação entre as características avaliadas por idade

\begin{tabular}{|c|c|c|c|c|c|c|c|c|c|c|}
\hline \multicolumn{11}{|c|}{ Eight years } \\
\hline & $\mathrm{BD}$ & LRS & $\mathrm{VEL}_{\mathrm{D}}$ & $\mathrm{VEL}_{\text {sat }}$ & $\mathrm{VEL}_{12}$ & $\operatorname{MOEd}_{\mathrm{D}}$ & MOEd $_{\text {sat }}$ & $\operatorname{MOEd}_{12}$ & $\mathrm{LGS}_{\text {sat }}$ & LGS $_{12}$ \\
\hline $\mathrm{BD}$ & 1,0 & $-0,17$ & $-0,22$ & $0,51 *$ & $0,50 *$ & $0,59 *$ & $0,87 * *$ & $0,95 * *$ & $0,68 * *$ & $0,65 * *$ \\
\hline LRS & $-0,17$ & 1,0 & 0,37 & $-0,03$ & $-0,19$ & 0,16 & $-0,11$ & $-0,19$ & 0,49 & $0,60 *$ \\
\hline $\mathrm{MOE}_{\mathrm{T}}$ & 0,44 & 0,10 & 0,47 & $0,63 *$ & 0,49 & $0,73 * *$ & $0,63 *$ & $0,52 *$ & $0,57 *$ & 0,47 \\
\hline TSp & 0,37 & 0,20 & 0,33 & 0,39 & 0,36 & $0,57 *$ & 0,42 & 0,41 & $0,50 *$ & 0,49 \\
\hline $\mathrm{LGS}_{\mathrm{T}}$ & 0,18 & $0,69 * *$ & $0,62 *$ & 0,43 & 0,44 & $0,65 *$ & 0,36 & 0,23 & $0,70 * *$ & $0,70 * *$ \\
\hline \multicolumn{11}{|c|}{ Thirteen years } \\
\hline & $\mathrm{BD}$ & LRS & $\mathrm{VEL}_{\mathrm{D}}$ & $\mathrm{VEL}_{\text {sat }}$ & VEL $_{12}$ & $\operatorname{MOEd}_{D}$ & $\operatorname{MOEd}_{\text {sat }}$ & $\operatorname{MOEd}_{12}$ & LGS $_{\text {sat }}$ & $\mathrm{LGS}_{12}$ \\
\hline $\mathrm{BD}$ & 1,0 & $-0,14$ & $-0,01$ & 0,15 & 0,08 & 0,10 & $0,68 * *$ & $0,80 * *$ & 0,17 & 0,15 \\
\hline LRS & $-0,14$ & 1,0 & $-0,51^{*}$ & 0,35 & 0,42 & $-0,53 *$ & 0,17 & 0,14 & $0,91 * *$ & $0,94 * *$ \\
\hline $\mathrm{MOE}_{\mathrm{T}}$ & 0,30 & 0,25 & $-0,15$ & $0,74 * *$ & $0,71 * *$ & $-0,13$ & $0,73 * *$ & $0,66 * *$ & $0,55^{*}$ & $0,49 *$ \\
\hline TSp & 0,33 & $-0,14$ & 0,06 & $0,66 * *$ & $0,54 *$ & 0,06 & $0,69 * *$ & $0,58 * *$ & 0,19 & 0,09 \\
\hline $\mathrm{LGS}_{\mathrm{T}}$ & 0,08 & $0,86 * *$ & $-0,45^{*}$ & $0,63 * *$ & $0,67^{* *}$ & $-0,45^{*}$ & $0,52 *$ & $0,47^{*}$ & $0,96 * *$ & $0,95 * *$ \\
\hline \multicolumn{11}{|c|}{ Fifteen years } \\
\hline & $\mathrm{BD}$ & LRS & $\mathrm{VEL}_{\mathrm{D}}$ & $\mathrm{VEL}_{\text {sat }}$ & $\mathrm{VEL}_{12}$ & MOEd $_{D}$ & MOEd $_{\text {sat }}$ & $\operatorname{MOEd}_{12}$ & $\mathrm{LGS}_{\text {sat }}$ & $\mathrm{LGS}_{12}$ \\
\hline $\mathrm{BD}$ & 1,0 & $0,46 *$ & $-0,15$ & 0,31 & 0,05 & $-0,06$ & $0,71 * *$ & $0,67 * *$ & $0,64 * *$ & $0,58 * *$ \\
\hline LRS & $0,46 *$ & 1,0 & 0,35 & 0,14 & 0,07 & 0,37 & 0,34 & 0,35 & $0,93 * *$ & $0,96 * *$ \\
\hline $\mathrm{MOE}_{\mathrm{T}}$ & $0,49 *$ & 0,32 & $-0,26$ & $0,71 * *$ & $0,74 * *$ & $-0,25$ & $0,76 * *$ & $0,87 * *$ & $0,54 *$ & $0,53 *$ \\
\hline TSp & 0,17 & 0,03 & 0,29 & 0,34 & 0,23 & 0,27 & 0,33 & 0,27 & 0,14 & 0,10 \\
\hline $\mathrm{LGS}_{\mathrm{T}}$ & $0,58 * *$ & $0,90 * *$ & 0,12 & $0,44^{*}$ & 0,39 & 0,15 & $0,62 * *$ & $0,66 * *$ & $0,96 * *$ & $0,97 * *$ \\
\hline \multicolumn{11}{|c|}{ Nineteen years } \\
\hline & $\mathrm{BD}$ & LRS & $\mathrm{VEL}_{\mathrm{D}}$ & $\mathrm{VEL}_{\text {sat }}$ & $\mathrm{VEL}_{12}$ & MOEd $_{\mathrm{D}}$ & MOEd $_{\text {sat }}$ & MOEd $_{12}$ & LGS $_{\text {sat }}$ & $\mathrm{LGS}_{12}$ \\
\hline $\mathrm{BD}$ & 1,0 & 0,09 & $-0,34$ & 0,17 & 0,18 & $-0,11$ & $0,65 * *$ & $0,79 * *$ & 0,25 & 0,26 \\
\hline LRS & 0,09 & 1,0 & 0,06 & $0,61 * *$ & $0,59 * *$ & 0,10 & $0,48 *$ & 0,41 & $0,96 * *$ & $0,97 * *$ \\
\hline $\mathrm{MOE}_{\mathrm{T}}$ & 0,00 & $0,61 * *$ & $-0,11$ & $0,71 * *$ & $0,63 * *$ & $-0,10$ & $0,54 *$ & 0,38 & $0,67 * *$ & $0,62 * *$ \\
\hline TSp & 0,24 & 0,39 & $-0,09$ & 0,32 & $0,45^{*}$ & $-0,05$ & 0,35 & $0,44 *$ & 0,42 & $0,46^{*}$ \\
\hline $\mathrm{LGS}_{\mathrm{T}}$ & 0,04 & $0,97 * *$ & $-0,02$ & $0,69 * *$ & $0,63 * *$ & 0,01 & $0,53^{*}$ & 0,41 & $0,96 * *$ & $0,94 * *$ \\
\hline
\end{tabular}

* and ** Significant at the levels of 5 and $1 \%$, respectively, by the t-test.

\section{CONCLUSIONS}

The results observed permits the following conclusions:

- Longitudinal residual strain (LRS) tended to increase with the age of the material;

- The stress wave velocity was much lower in the radial direction, probably due to the internal defects of the wood and crossing the lignin component, which is an amorphous and inelastic polymer;

- The stress wave velocity and the dynamic modulus of elasticity, obtained in the longitudinal direction, increased from the green condition to the $12 \%$ of moisture content wood;

- The modulus of elasticity of the tension parallel to the grain test was superior to the dynamic modulus of elasticity in the longitudinal direction and with wood in the $12 \%$ of moisture content condition at all ages assessed, that reflected directly on the estimates of the longitudinal growth stress;

- The growth stress estimates presented the same performance tendency as LRS, that is, to increase with the age of the material;

- The basic density presented higher, positive and significant correlations with the dynamic modulus of elasticity estimated in the longitudinal direction for the green condition and $12 \%$ of moisture content wood, at all ages assessed;

- LRS correlated positively and significantly with all the estimates of the longitudinal growth stress, and with greatest magnitude at 13, 15 and 19 years of age;

- The LRS can be considered an indirect and reliable estimate of the longitudinal growth stresses;

- All the longitudinal growth stresses estimated presented high positive and significant correlations between themselves. 


\section{REFERENCES}

AMERICAN SOCIETY FOR TESTING AND MATERIALS - ASTM. Annual book of ASTM standards. Denvers, 1997. 679 p. D143/94: Standard methods of testing small clear specimens of timber, p. 23-53, 1997.

ARCHER, R.R. Growth stresses and strains in trees. Berlin: Springer-Verlag, 1986. 24p.

FERRAND, J. C. Growth stresses and silviculture of eucalyptus. Australian Forest

Research, Melbourne, v.13, n.1, p.75-81, 1983.

GAIOTTO, M.R. Avaliação da madeira de Eucalyptus saligna e Eucalyptus urophylla para produção de lâmina. Piracicaba, ESALQ/USP, 1993. 119p. (Dissertação MS).

KANG, H.; BOOKER, R.E. Variation of stress wave velocity with MC and temperature. SpringerVerlag, Wood Science and Technology, n.36, p.41-54, 2002.

KUBLER, H. Growth stresses in trees and related wood properties. Forest Products Abstracts, Oxford, v.10, n.3, p.61-119, 1987.

LIMA, J.T.; TRUGILHO, P.F.; ROSADO, S.C.S.; CRUZ, C.R. Deformações residuais longitudinais decorrentes de tensões de crescimento em Eucalyptus e suas associações com outras propriedades. Revista Árvore, v.28, n.1, p.107-116, 2004.

LISBOA, C.D.J. Estudo das tensões de crescimento em toras de Eucalyptus grandis Hill ex. Maiden. 1993. Curitiba: UFPR, 298 p. (Tese Doutorado em Engenharia Florestal) Universidade Federal do Paraná, 1993.

MALAN, F. S. The control and-splitting in saw logs: A short literature review. Pretoria, South African Forestry Journal, n.109, p. 14-8, 1979.
MATOS, J.L.M. Estudos sobre a produção de painéis estruturais de lâminas paralelas de Pinus taeda L. Curitiba, UFPR, 117 p. (Tese Doutorado em Engenharia Florestal) Universidade Federal do Paraná, 2003.

NICHOLSON, J.E. A rapid method for estimating longitudinal growth stresses in logs. Wood Science and Technology, v.5, n.1, p.40-48, 1971.

POLGE, H.; THIERCELIN, F. Growth stress appraisal through incremente core measurements. Wood Science, v.12, n.2, 1979. p.86-92.

SECRETARIA DE ESTADO DAAGRICULTURA E POLÍTICA RURAL DE SANTA CATARIANA.

Anuário da agricultura de Santa Catarina, Florianópolis, v.1, 287 p. 2003.

TRUGILHO, P.F.; LIMA, J.L.; ROSADO, S.C.S.; MENDES, L.M.; MORI, F.A.; SOUZA, M.A.M. Avaliação da tensão de crescimento em clones de Eucalyptus. Floresta e Ambiente, Seropédica, v. 9, n. 1, p. 38-44, 2002.

TRUGILHO, P.F.; IWAKIRI, S.; MATOS, J.L.M.; SALDANHA, L.K. Efeitos da idade e da classe diamétrica na deformação residual longitudinal em árvores de Eucalyptus dunnii. Revista Árvore, v.28, n.5, p. 725-731, 2004.

van WYK, J. L., Hardwood sawmilling can have a bright future in South Africa. South

African Forestry Journal, Pretoria, n.109, p.47-53, 1978.

WILHELMY, V. \& KUBLER, H. Stresses and checks in log ends from relieved growth stresses. Wood Science, Madison, v.6, n.2, p. 136-42, 1973.

WILKINS, A. P. Nature and origin of growth stress in trees. Australian Forestry, Canberra, v.49, n.1, p 56 - 62, 1986. 